\title{
The Divine Feminine: Indigenous Festivals in the North Coastal Districts of Andhra Pradesh
}

\author{
I. S. V. Manjula Haragopal, N.Jagadamba \& I.Syamala Devi \\ Vignan's Institute of Information Technology, Visakhapatnam
}

\begin{abstract}
The divine feminine is apparent in myriad forms across this world. We see Her in the animate and the inanimate; in us and in others; in the temporal and the ethereal. We find Her revered in various ways too and the expression of this reverence again sees a myriad shades depending on the geographical locale. In the coastal districts of Andhra Pradesh, India, we see Her as an enigmatic all pervasive omnipotent power who is appeased with humble offerings of neem leaves and porridge. At the same time her wrath knows no bounds if she is disturbed in any way. Simple people with simple faith offer their prayers in the most fervent and genuine potential and the indigenous festivals are true witness to this. This paper is collective representation of the manifestations of the Divine Feminine in the coastal districts of Andhra Pradesh and the charming stories behind the 'ammas' threaded together from oral tradition of narrations.
\end{abstract}

Key words: divine, feminine, devotee, festival, amma, deities, indigenous, Andhra Pradesh

In ancient times India was a country that had strong matriarchal bearings. All household women were regarded as Gribalakshmi symbolically meaning 'the prosperity of the house'. In every village, at the entrance, there was always a goddess called Grama Devatha or 'village deity'. The people always worship her for their health, wealth and prosperity. Once a year they perform her festival in a grand way. The people think that the goddess always protects them from evil spirits and viral fevers which occur mostly in the months of March and April. So, many festivals of the village deities are performed in these months. The Prasadam or "offerings" consists of Ragi porridge or rice and dhal accompanied with drumstick leaves cooked with gingely extract powder as curry and fruits, coconuts, flowers, kumkum (saffron), haldi (Turmeric), chandan (sandal Paste), red bangles, red sari with yellow flower print, are offered to the deity.

In every festival of the Goddess in any village or town, on the festival day, people stream to the venue with earthen pots filled with cooked food. The pots are covered with clay plates in which an oil lamp burns and these pots with lamps are carried on the heads by the devotees. The pot is always decorated with neem leaves. As the devotees fulfill their vows, their relatives spread the saris on the way on which the pot bearers walk towards the temple. Some devotees prepare the food in the presence of the deities in their temples, which they eat after the divine offering. Some people who take the oath of offering a goat or a hen to the goddess do so by sacrificing them on the "Balipeetam" or sacrificial altar of the temple. Now a days the Government has placed many curbs on animal sacrifice. Then the sacrificial meat is cooked and served to the Goddess and her brother.

According to many legends there are innumerable goddesses who are sisters and their only brother is 'Pothuraju,' whom everybody worships before entering the shrine of the Goddess. In most of the villages, devotees first encounter 'Pothuraju,' as He stands prominently in front of the Temple as a guard to his sister- the Goddess. Nookalamma, the presiding deity of Anakapalli is a 
majestic awe-inspiring deity whose devotees throng to her festival to lay at her feet all the traditional offerings that are considered close to her heart.

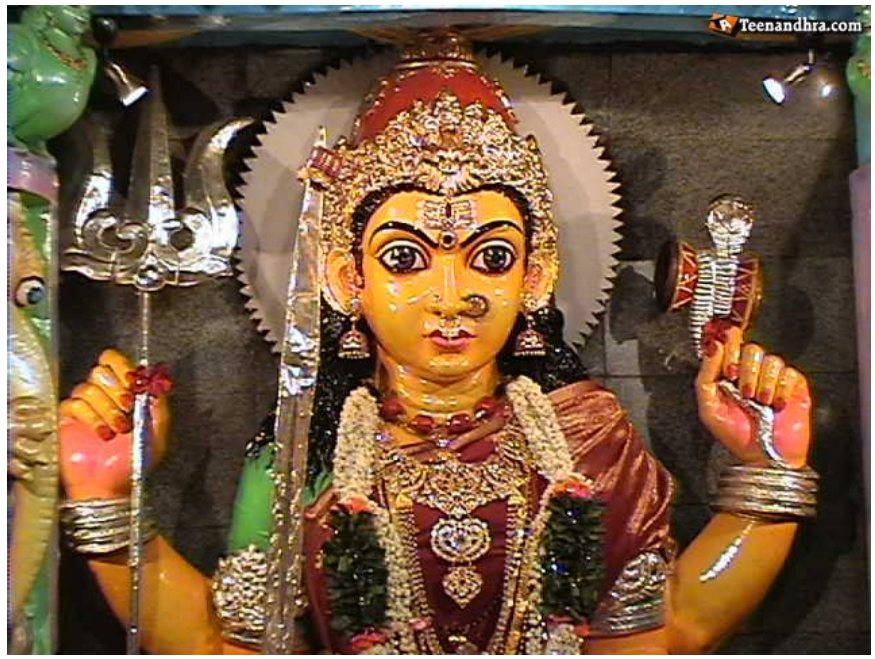

(Goddess Nookalamma in all her splendor)

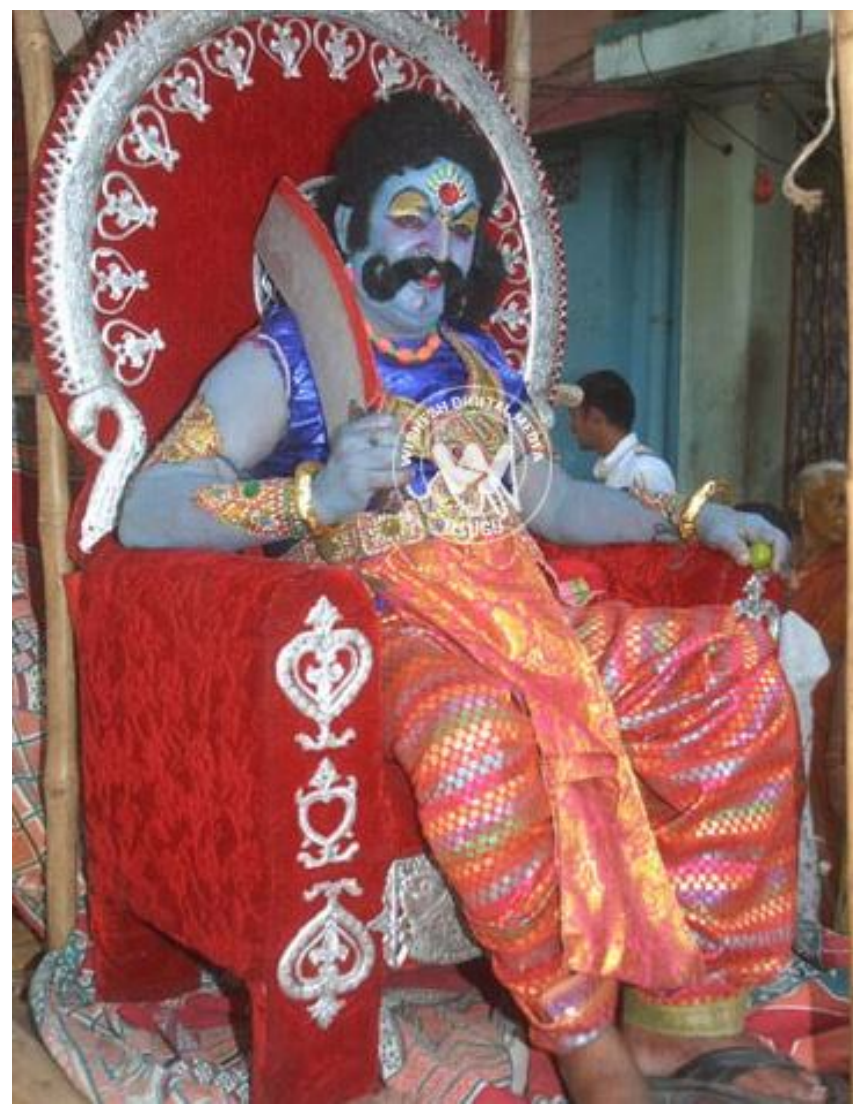

(An artist dressed as Pothuraju, brother of the village deity)

From ancient times we Indians have personified our nation as Mother India-Bharat Mata and the region Andhra Pradesh as Telugu Thalli. The rivers are also bestowed upon feminine names and sacred plants like Tulasi are also worshiped with feminine attributes in the Hindu households. 
Further, the protecting divine forces of villages are invariably feminine. People believe that the Goddess protects them from all evils. So as a way of celebrating her blessings these festivals are performed once a year. These festivals are performed irrespective of any religion, caste or creed. The goddesses are worshiped as Durga or Lakshmi or Sarasvathi or Kali according to local belief. So, while worshiping they chant the corresponding mantras of the deity. If it is Durga's incarnation "Uma Sambhavi katyayani..." and if it is Lakshmi's incarnation, "Namastestu Maha Maye" and if is Saraswathi "Saraswathi namasthubyam". Along with the chanting of the 1000 names or 108 names, Havans, homams, mass kumkum pujas and Lakhsha Deepam pujas (One Lakh lamps) are performed.

The 'deities' endearingly called "amma" suffixed to their names, are worshipped with ardent fervor in the coastal areas of Visakhapatnam, Andhra Pradesh. Though the offerings made to the goddesses are similar in many ways as described above, each Deity has a festival time and purpose assigned to her. Each Goddess stands magnificent accepting her due and protecting her locality, never letting down her devotees. However, the days considered as auspicious to each deity vary and each festival carries its own convictions and customs.

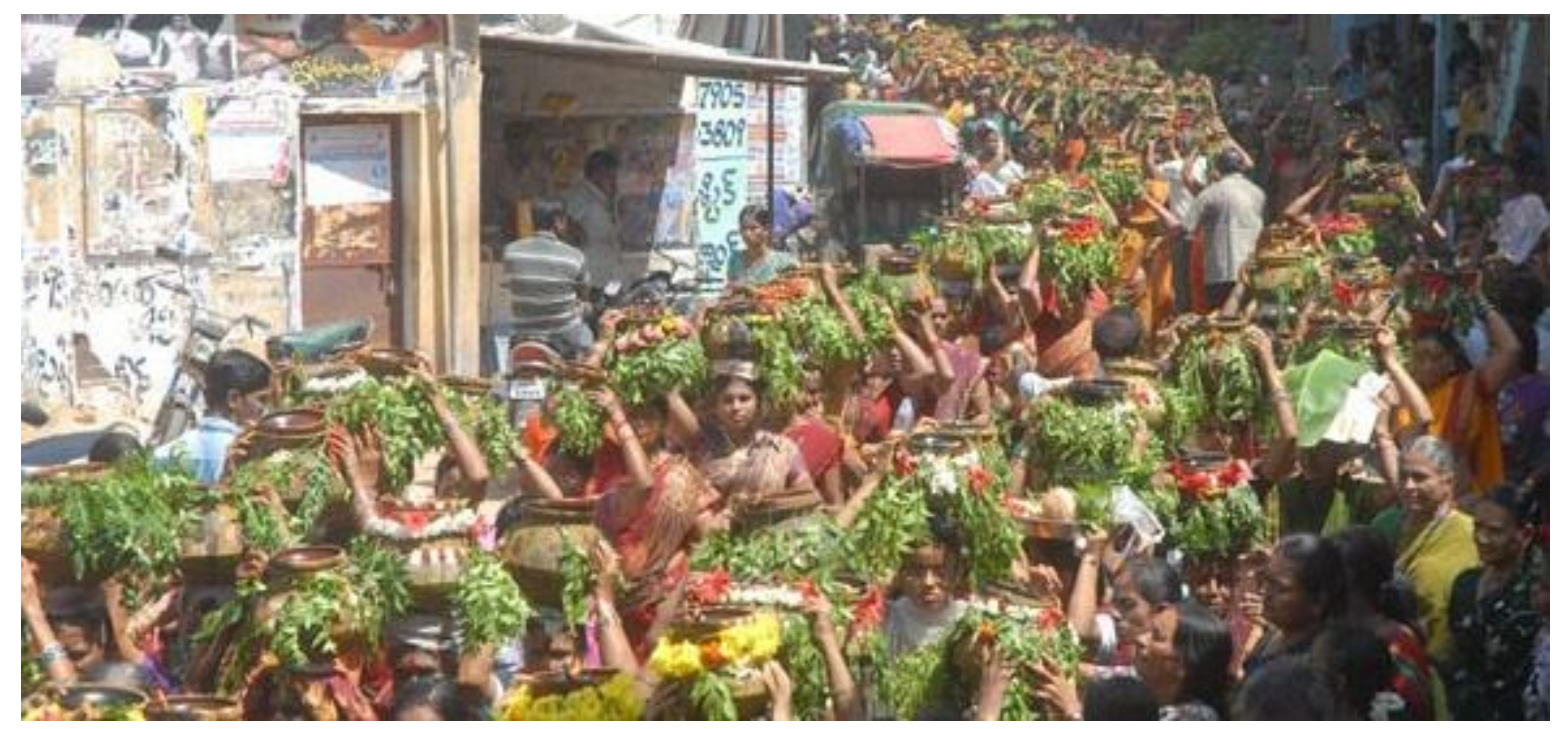

(Devotees in a procession with clay pots decorated with neem leaves)

On all these days of the celebration, people perform classical and folk dances. Classical music and folk songs are sung and played to entertain the devotees. Some people light a big fire in a long pit and devotees who take a vow for the wish fulfilled or to be fulfilled walk on glowing embers after the fire subsides, from one end to the other, once or several times according to their oath. After the killing of animals was banned by the Government, pumpkins which are filled with baldi and kum kum and water are broken near the temple as an offering instead of animals. The mood of these festivals is a mix of awe and fear for the presiding deity as a protector as well as the destroyer with immense primeval energy.

The festival of Kanaka Mahalakshmi has a patriotic legend attached, which says that at the time of foreign invasion a local woman, ferociously fought against the invaders and while fighting was hit on the back with the sword and she jumped into the nearby well with her children. After a very long time she appeared in the dream of a Brahmin who was living near the well. She said that she was residing in the well and guided him to take her out and build a home for her near the well. A compact roofless temple was constructed for her that allows all the elements of nature to be in contact with her. Her devotees, now innumerable in number, place a lamp before her, break a 
coconut, offer flowers, milk, apply saffron and turmeric to her face and perform aarthi. From that day on wards, the residents of Vizag and nearby towns and villages visit her shrine and perform puja. In December, during the month of Margasira, which is considered her month, enormous crowds throng her temple and offer prayers and make offerings. In the evening the popular traditional programs like, Harikathas, Burrakathas or Purana Patanam are performed late into the night for the moral and spiritual edification of the Devotees.

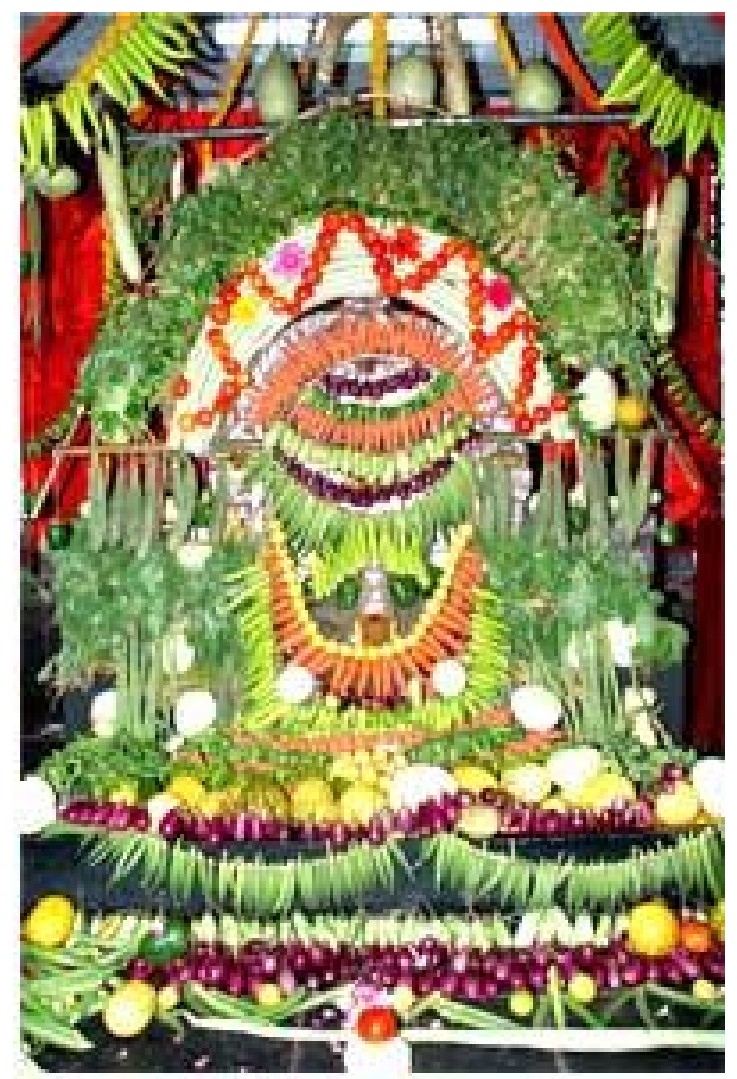

(Goddess Kanaka Mahalakhsmi decorated with variety of native vegetables)

In Chinna waltair of Visakhapatnam dwells the goddess Kanakamma, whose festival comes in the month of April. The people of this region belonging to all communities wait eagerly for this festival. They perform ballaveshalu, that is enacting scenes from the Ramayana, Mahabharata and Bhagavatam on bullock carts by youth and children. The best performance is awarded at the end of the festival. The locals invite the relatives from other villages and towns for feasts hosted in their houses.

Sixty kilometers from Visakhapatnam, the historical town of Vizianagaram thrives as a business centre for far and near business families. In Vizianagaram resides the most adorable goddess Pydithallamma. The legend says that she was the girl child of the Vijayanagaram kings and had sacrificed her life for the benefit of her family and became a Goddess. Her festival is performed in the month of October. As the festivals of all Goddesses, this festival too is performed with exuberance for several days. The unique feature of this festival is the Sirimanu ritual performed on the occasion. The priest of the temple observes upavasa (fasting) and does meditation. A few days ahead of the festival, the goddess appears in his dream and speaks about the special tree which is to be used for the ritual. The tree is identified and the trunk of the tree is procured and tempered for the occasion. 


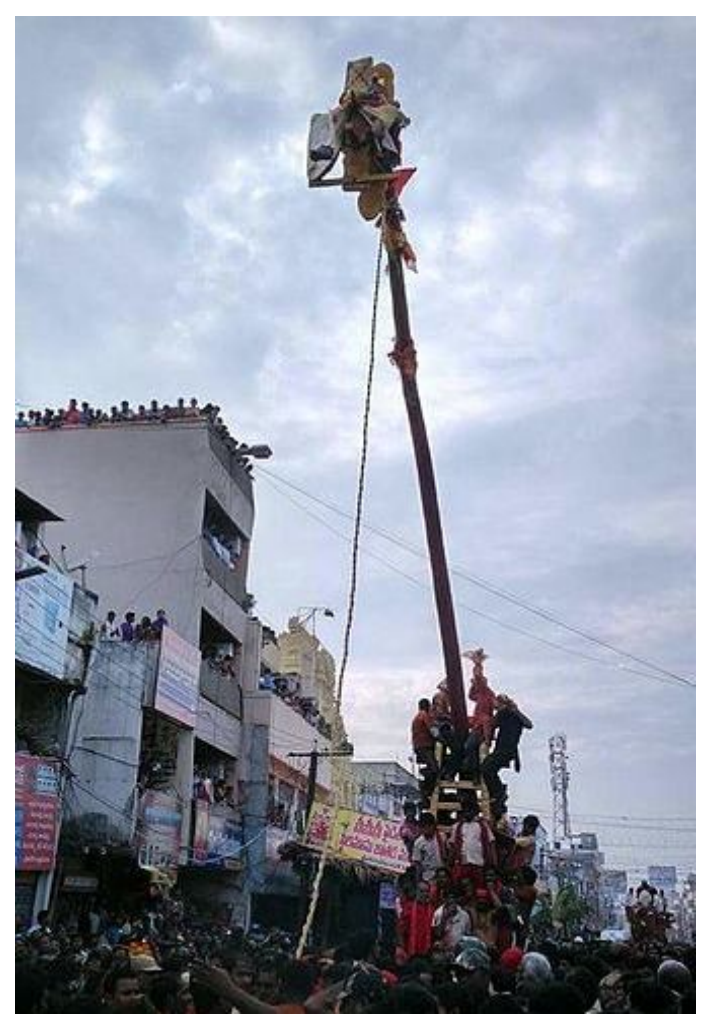

(Procession of the Sirimanu)

The trunk is attached to a ceremonial cart and at the top end of the trunk an improvised swing is tide. The priest is seated there and the cart is drawn from the temple to the king's fort which is considered the maternal home of the goddess. On reaching there the king's family offers saris, раsири (turmeric) and kumkum (saffron), bangles to the deity according to their faith. The cart returns to the temple. The festival concludes with much pomp and piety. The local people invite their relatives for feasts and to witness 'puliveshalu' (dance in tiger costume). The fishermen community traditionally offers a decorated net as a token of their affection and reverence to the Goddess and lead the procession. This Sirirmanu festival invites much media attention and lakhs of people participate with immense fervour in the festivities.

Vizianagaram has a very family specific festival called Sathamma thali (Shatamma's tali) Puja. The family members of a particular surname invoke the blessings of the 'Goddess' on auspicious occasions such as child birth, house- warming, marriage etc. Therefore the festival of vow is performed before the family conducts a function. The family invites the members of the extended families, friends and relatives. The hosts stay fasting the entire day and towards late afternoon start preparations for the feast of Prasad which is actually a lavish dinner including sweets, vegetarian and non-vegetarian preparations. There is an interesting belief that goes with this festival. A scion of the family many generations ago was an invitee at the feast hosted by a vegetarian family. After partaking the food, on his way home, he said to himself, "What use is it for the Mother to eat all those vegetables? If she visits my home I shall serve her the delicious Jella (a type of fish) curry and offer toddy with it. That is what makes a true feast!" That night, the Goddess is said to have appeared him in a vision and said, "You have invited me for the feast and I am here. Serve it". 


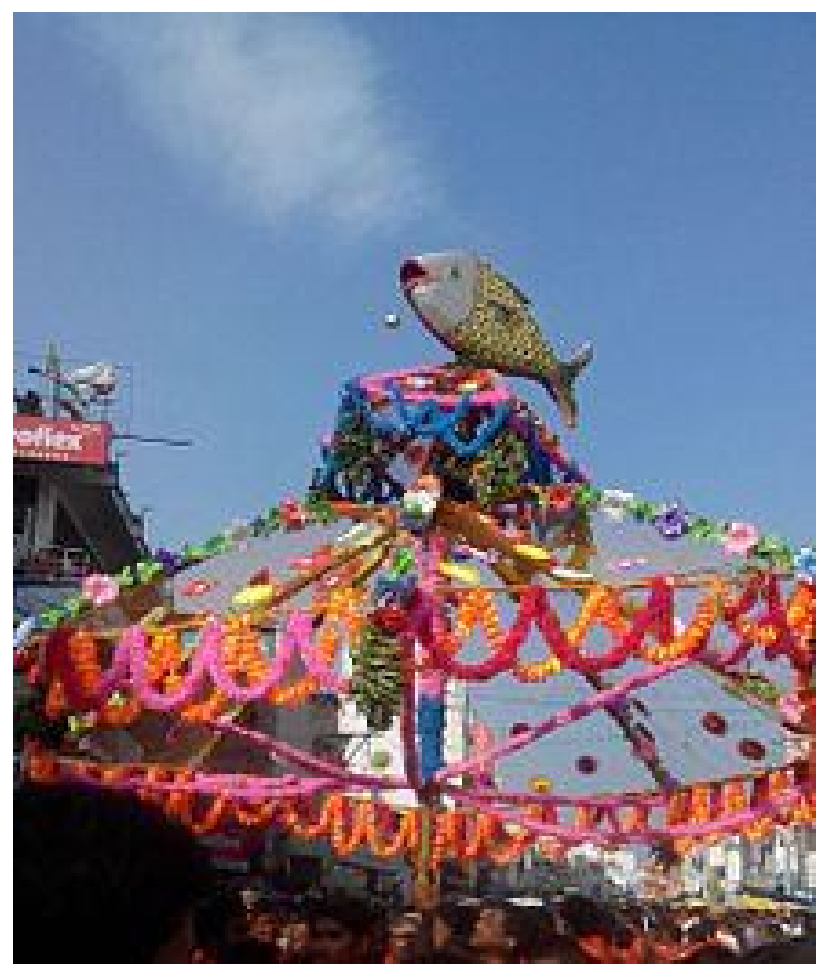

(Fishermen's net in Sirimanothsavam)

From that day onwards for generations, the family descendants ensured that the feast was prepared and served, particularly with the special dishes as promised to the Goddess. In the evening cooked rice is upturned as a heaped mound on mat of palm leaves, with other dishes surrounding it. The incense for the day is tobacco and the drink is toddy. The room of the feast is closed and the deity is invoked to enjoy the feast. When the door was opened the finger and hand prints were noticed on rice and other dishes as a living proof of the goddess partaking the meal. However advanced, educated or how far away from home the people of this region may be, they ensure that they offer their due prayers and respect to their village, family or town deity seeking her blessings on all occasions.

In most parts of Andhra Pradesh the dhobi community or washer men celebrate annually "Balla panduga" that involves the worship of the washing stone on which they wash the people's clothes. It falls in January every year after Makara Sankranti. The washer men do not wash clothes for a period of ten days. The stone is washed neatly and applied with haldi and kumkum. In the earlier days a pig was sacrificed and its blood smeared on the stone as a part of the ritual, but in the present day context hens and goats are offered as sacrifice and goddess "Appalamma" worshipped. They worship her offering coconuts, fruits and flowers. On the festival day many shops are erected selling bangles, utensils, eatables, fruits, flowers, photos of Gods and so on. There is a carnival and some people dress up like tigers with their bodies painted all over with stripes. Tails are also attached to their backs. The whole village reverberates with jingles from decorated bullock carts on which electrical lights are arranged. There are some acting as Rama, Sita, Lakshmana and Hanuman and some scenes from puranic episodes are also enacted. Skits, dances and cinemas are staged on the roads till midnight. Residents invite relatives and friends and enjoy the days with fun and piety. Everybody in the locality irrespective of the caste participate in this function. The people of dhobi community believe that by performing this ritual they will get the blessings of the Goddess and they will all be happy and healthy and prosperous throughout the year. 
The fishermen folk of the Visakhapatnam have two colonies: one, near the beach at the town and the other near the beach of pedawaltair. Their goddess is Polamamba. Hers is a very big temple consisting of smaller temples in the precincts of the big temple with goddesses known to be her sisters. The fishermen are the ardent devotees of these goddesses. The names of the sister are Kunchamamba and Neelamamba. The fishermen community performs their festival from April to May. They collect huge donation from the people and perform this festival lavishly. They as usual invite all of their people from far and near for this festival. Not only the fisher folk but all other caste people also worship her with great devotion. These people also perform "Gangamma Jatara"

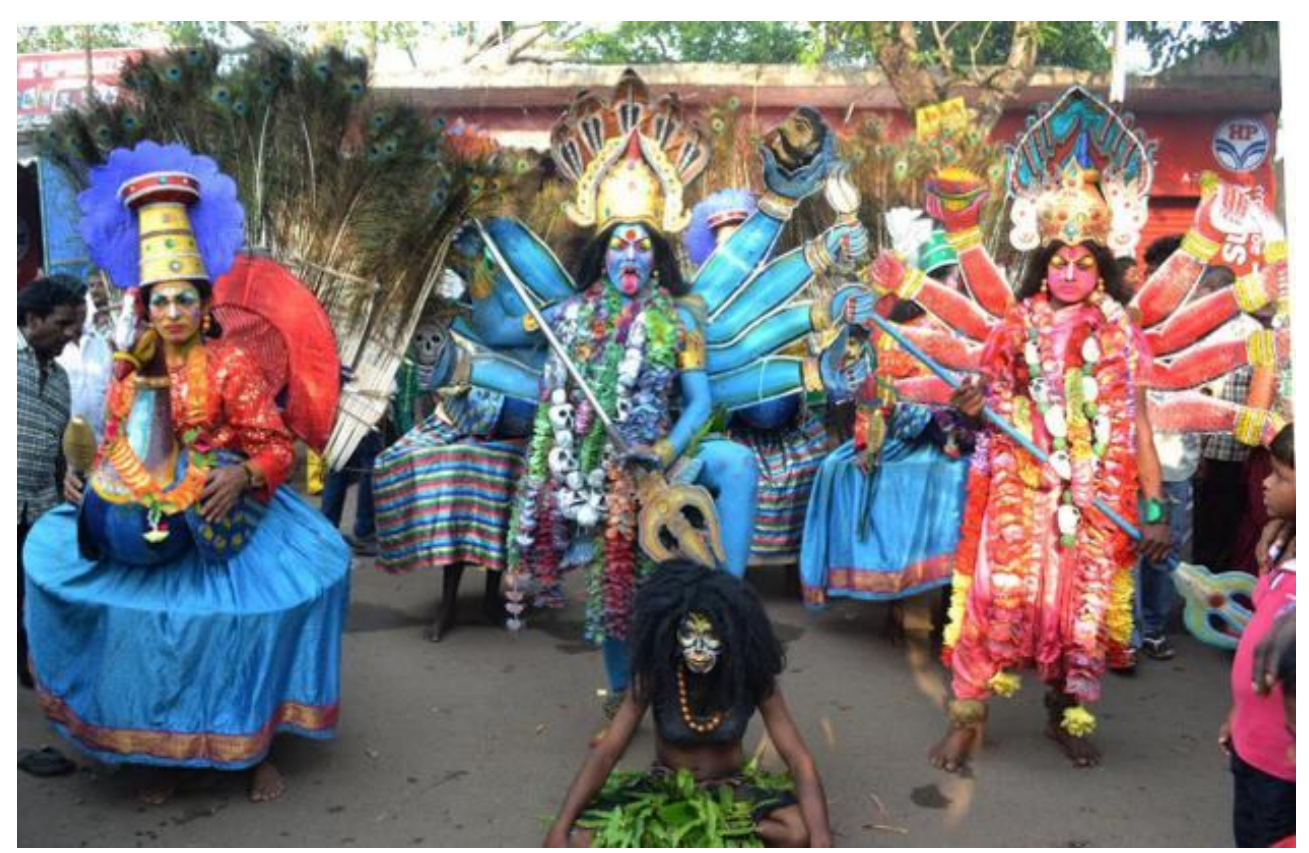

(Folk artistes performing during the 'Gangamma jatara' at the fishing harbour in Visakhapatnam -Photo: C.V. SUBRAHMANYAM, The Hindu)

As their living is dependent on water bodies like ocean, sea, lakes, or rivers, the women go to the sea with water laden pots in which they mix milk, haldi, kumkum and decorate the pot with neem leaves and do puja to the sea. They mix this liquid in the sea and ask the sea God or goddess Gangamma to save their men from all calamities when they go on sea for fishing. They pray for their longevity. Hundreds of women clad in yellow or red sarees go in crowds to perform this jatara. As usual both these festivals are performed with much devotion and include street performances "veshalu", puliveshalu, drama, dances and so on. Whole of the village is decorated with lights and every house is decorated with mango leaves and marigold flowers.

Though foreign invaders ruled our country for hundreds of years they all could not wipe out indigenous faiths and customs and Samskruti (culture). The natives believe that the Supreme power is manifest in all forms, viz. man or woman or statue or tree or river helps and saves mankind from all hurdles of life, showering the bliss of contentment and showing a ray of hope-what better form can this benign force take rather than that of the mother or "amma" or the Divine Feminine. 


\author{
Web Sources \\ https://en.wikipedia.org/wiki/Sirimanothsavam \\ http://kanakamahalakshmiphotogallery.com \\ http://www.thehindu.com/news/cities/Visakhapatnam/gangamma-jatara-festive-fervour/article6062137.ece \\ http://www.teluguwishesh.com/srungaram/237-vizag-news/45417-sri-nookalamma-ammavari-jatara-in- \\ anakapalli.html \\ http://blogs.allmytrip.in/wp-content/uploads/2014/07/Madhurawada-SRI-NOOKAMBICA- \\ AMMAVARI-4.jpg
}

Dr. I.S.V Manjula Hara Gopal is presently working as Professor at Vignan's Institute of Information Technology, Visakhapatnam. She is a certified examiner for British Council and Trinity College, London. She is also Chief Editor of the College News Letter 'The Aim' (60 issues till date). She also acts as Facilitator and Resource Person in Workshops on Communication Skills. She received Best Thesis Award for Ph.D. Dissertation, (2001-2002), Dept. of English, Andhra University, Visakhapatnam and was honoured with Pratibha Award by her institution. She has published research papers and poems.

N. Jagadamba, born in Visakhapatnam district, Andhra Pradesh, has completed 75 years of age, enriching herself and her associates with her wide knowledge of local customs and traditions and carrying on the legacy of oral narrative of her region. She completed Pravesika in Hindi under the initiation of Dakshina Bharata Hindi Pracharika Samiti in 1960s. With a keen interest to understand the slokas and scriptures in their original form, she completed Certificate course in Sanskrit under the Adult Education Programme of Andhra University in her 60s. She constantly upgrades her knowledge of the past and the present with her insatiable interest for knowledge.

I.Syamala Devi, born in the historical town of Vizianagaram, Andhra Pradesh, is ably equipped with innate knowledge of the minutiae of the rich cultural tradition and legacy of north coastal Andhra Pradesh. She is also a classical dancer, trained under the tutelage of world renowned Bharatnatyam exponent, Dr. D.Y. Sampath Kumar. Well-read and well-traveled, with her immense exposure to diverse ethnic practices, she has held the inherited cultural lifestyle alive while concurrently embracing the progressive advances of modernism. Having completed six decades of enriching life, she has keen interest in emerging forms of thought. 